\title{
Music Education and Youth Empowerment: A Conceptual Clarification
}

\author{
G. C. Abiogu1, I. N. Mbaji1, A. O. Adeogun'2 \\ ${ }^{1}$ Department of Educational Foundations, University of Nigeria, Nsukka, Nigeria \\ ${ }^{2}$ Department of Music, University of Nigeria, Nsukka, Nigeria \\ Email: abiogu@yahoo.com
}

Received 22 January 2015; accepted 10 February 2015; published 12 February 2015

Copyright (C) 2015 by authors and Scientific Research Publishing Inc.

This work is licensed under the Creative Commons Attribution International License (CC BY). http://creativecommons.org/licenses/by/4.0/

\section{Abstract}

This paper is a conceptual clarification of the nexus between music education and youth empowerment. It is also an exposition of how music education can be utilized for the empowerment of the Nigerian youths with a brief incursion into the meaning of education and its need for national development. The paper considers music education as a performance art which involves unique educational activities designed to enable the youths to achieve self-realization and life adjustment in the society. The conceptual clarifications touch upon some philosophical principles which guide music education in its application as a tool of empowerment of youths and how Nigerian government can borrow a leaf from some of the African countries who partner with non-governmental organizations (NGOs) such as the Music Crossroad International (MCI) organization to empower their youths and communities. Through the creation of such musical opportunities through partnerships by such countries, implications for Nigeria are drawn with recommendations and conclusions.

\section{Keywords}

Conceptual Clarifications, Music Education, Performance Art, Philosophical Principles, Educational Activities, Youths Empowerment, Self-Realization, Musical Opportunities and Life Adjustment in the Society

\section{Introduction}

The conceptual essence of education has made nations to accept in principle and practice its importance as a vehicle for youth empowerment and national development. Education is the bedrock for the development of a nation. Thus, the efficacy of sound and quality education in the development of an individual's innate talents and 
in the discovery of natural endowment can never be over-emphasized. In keeping with the policy position of the Federal Government of Nigeria (2004: 4) education was officially adopted as an instrument "par excellence" for achieving national development. In the plethora of educational empowerment definitions, Oluwaseyi (2009) stated that E. B. Castle defined education as what happens to the individual from the day one is born to the day one dies. Arguably, this definition is too general in scope, for it permits all experiences that happen to an individual from birth to death to be called education.

The necessity to improve on definitions such as the one above informed the idea of Balogun (2008) that education is an act or experience that has a formative effect on the mind, character and physical ability of the individual. If education is an act or experience, it is a process of the activity to preserve, develop and transmit the culture of a people from one generation to another. In other words, education responds to the cultural, linguistic, and environmental needs of the people.

In the same development, music is a common language that reaches across boundaries to bring cultures together and it creates a global understanding. It is determined, interpreted and dressed or colored by culture, and cultural environment of a people. Since music is part of human culture, which should be imbibed, projected, and perfectly transmitted, it ought to have a recognized process by which it could be acquired. In the light of the above, Okafor (2007) highlighted that such recognized process of transmission of globalized understanding should be framed conceptually within the educational policy and musical education curriculum respectively of a state. As music is a type of language, it has to be learnt through educational process. The critical need for music education in the society has in the past constituted the subject matter of philosophical speculation by some philosophers. Even when the clarification is not substantially philosophical, let us highlight one philosophical note from the past.

For instance, Plato (427-347 B.C.) as portrayed in Grube and Reeve (1992) placed it on record that music has the power of producing certain positive effects on the moral character of the human soul. This explains why music education of the youths was not treated with levity of mind in Plato's ideal Republic. On the part of Shakespeare (1564-1616) as attested in Wood and Wood (1901), any man who has no music in himself and cannot be moved with concord of sweet sounds, is dangerous and commit treason. To this effect, the envisioned purpose of this paper is to advocate for a policy position that to the effect that Nigerian youths should be empowered through the agency of music education. Music is to be learnt and lived out as a performance art used for the inculcation of good citizenship and employable values and skills.

\subsection{Teaching and Learning of Music Education as a Performance Art}

Music education is a field of study associated with the teaching and learning of music. It touches on all domains of learning, including the psychomotor domain (the development of skills), the cognitive domain (the acquisition of knowledge), and in significant ways the affective domain, which includes music appreciation and sensitivity. From the perspective of Nwökenna (2008), the term music education includes all deliberate efforts to educate people in music as a specialization regardless of the area of emphasis. Recognizing the importance of music education in national development, the Federal Government of Nigeria (2004) in the National Policy on Education listed music as one of the courses to be studied at all levels of education.

Music education in the view of Reimer (1989) is construed as a form of aesthetic education. This position of Reimer has been questioned because, the use of music education as aesthetic educational movement in 1960s and early 1970s was made by some education teachers to emphasize the teaching of music as part of a humanities course curriculum rather than as a performance art. In contrast to Reimer's position, music education can be considered as a performance art since one thinks about it, applies it and performs it with one's students. Music education is therefore praxal as it cultivates music performance and improvisation as its central activities. Supporting the above, Gardiner (2003) observed that music education is an extremely rich kind of experience in the sense that it requires cognition, emotion and aesthetics. It develops performance skills and individual capabilities. These qualities have to be developed, synchronized and integrated to enable the learner in music education to discover the interrelatedness between music and history, music and mathematics, music and social studies, music and political science; music and languages, as well as music and philosophy.

On the part of Pythagoras (c. 600 B.C.), Plato (428-370 B.C.) and Confucius (551-479 B.C.) they concurred in Benton (1974) that music is a performance art. They argued that performance arts are not just affective and expressive, but deeply cognitive. The arts develop in the learner the means of correct thinking which among 
other things include: careful observation of the world, mental representation of what is observed or conceptualized, abstraction from complexity, pattern recognition and development, symbolic and metaphoric representation, and qualitative judgment.

Inferring from the above, music education as art refers to a kind of educational activities designed to enable the youth interested in music to live and adjust their lives in the society. This implies that music education is an educational activity which has a definite purpose, and must therefore be guided by well articulated conceptual, philosophical and practical principles. What then are the philosophical principles that can guide music education?

\subsection{Music Education and Its Philosophical Principles}

Philosophy is an activity of logical reasoning. It is the rational exploration of those aspects of the problems which are theoretical, and capable of being resolved or at least elucidated by rational dialogue. Philosophy according to Burtt (2008), begins with the explication of the language of discourse on a particular topic on the premise that if there is no agreement on the meaning of words being used there will be no meaningful discourse or dialogue. Hence the clarification of language and analysis of assumptions in music as well constituted the pre-eminent task of philosophy. The employment of philosophy is to act as a tool for conceptual clarification to make a case for the role of music education in both youth and national development.

Since every discipline has its language peculiarities in terms of the technical use of words, concepts and terminologies, music education cannot be different in its own discipline. As an emerging field of study and even an institutional practice it has developed a set of language expressions whose philosophy and technical interpretative meaning are peculiar to its field. For instance, music language expressions interalia include: phonological organization; fundamental assumptions, logical rationalization and computation. These expressions as Reimer (1989) and Okafor (2007) highlighted, convey deeper meaning to scholars and practitioners in the discipline of music than they do to the layman on the street of music. Most probably, some clarifications of these music-language expressions may, to an extent, bring out the philosophical aspects of the principles that guide music education.

\subsection{Conceptual Clarification of Music Language Expressions}

\subsubsection{Phonological Organization in Music Education}

Phonology according to Marius (1991) means the study of the distribution and patterning of speech sounds used in a language. It as well concerns the tacit rules governing pronunciation. In music education it is the organization of the words which define the language of the music. It refers to the structuring and restructuring of the words to be used in music. In the analysis of Benton (1974) a song or music consists of three elements: the words or lyrics, the mode and the rhythm. The mode and the rhythm must suitably conform to the words. Here the philosophical aspect of the principle that guides music education lies in the lyrics. The lyrics can be used to prepare an European child in the manner of European music. In the same development for the African who uses sounds in his/her daily labour, musical lyrics can be used to prepare the African child on how to participate in all areas of adult activity such as hunting, fishing, funeral and dancing.

\subsubsection{Fundamental Assumptions in Music Education}

There are certain philosophical assumptions which underlie the practices of professional musicians and their scholars. For example, the ideas by which the musician is guided, lead to a greater attainment of the result which is always sought in the aesthetic enterprise. The musician must be a master of the techniques of his art. Regarding the issue of fundamental assumptions in music education, Elliot (1995) posed the fundamental question: Who could become a great musician if such a person does not understand the structure of sound in its modes of pitch, timbre and intensity, and the characteristic feelings with the main variations by which they are bound up? The assumption here is that the musician must have a great idea to express. It must be an idea that can symbolize in a unique form, a universal human emotion, or vividly summarizes a deep and growing tendency of the age, to increase individual's sensitivity to beauty.

\subsubsection{Logical Rationalization and Computation in Music Education}

Music as a human product has method and logic peculiar to its nature. Unlike most other human productions, the 
learner starts his music by constructing and combining lines as well as objects or instruments of musical sounds. Here, the musician uses an inherent musical logic which dictates how the musical lines being constructed or combined should be continued to formulate the form of the music. A line of music as Byrne and Sheridan (2008) pointed out begins with a complete musical statement known as a theme or idea. This theme which could be of long or short span has a complete "life" of its own, that is, a beginning and a restful end. It becomes the point of reference for the purpose of distinguishing one item of music event from another, in the repertory of music group or musical culture. This method of musical lines computation involves mental rationalization and calculation which are often philosophically derived. It embraces humanistic values as they relate to contemporary musical-educational life, while respecting the musical traditions of the past. Arguably, since music education is purely a field of human activity guided by some philosophical principles, how can it serve as a means of empowering Nigerian youths?

\section{Music Education for Nigerian Youth Empowerment: A Situational Analysis and Advocacy}

The country Nigeria in the analysis of Somefun (2013) seems to be in a state of anomy. The foundational problems plaguing the country affect the society in quantum, and particularly youths who are the leaders of tomorrow. The nation-state sinks in the sand of egoistical causes. The youth's search for a sense of belonging to social change, according to Ndibe (2013), yielded little or no result. What is more, the youths themselves contributed to the outcome of anarchic tension, which brands the ugly state of the Nigeria as a nation today. To avert the impending socio-economic crisis of hunger, poverty, and unemployment, the Nigerian government has tried to initiate some empowerment programs for the youths.

The empowerment programs are the National Directorate of Employment (NDE) in 1984; the National Economic Empowerment and Development Strategy (NEEDS), which is part of the Government's efforts to achieve the goals of the United Nation's Millennium Development Goals (MDGs) in 2001. At the local level some other empowerment programs were also implemented. From the point of view of Emielu (2005) and Egbunefu (2012), the empowerment programs organized by the government, seem not to have made much significant impact on the youth populace.

Thus, for effective empowerment of the youths with music education, the Nigerian government should collaborate with some philanthropists and other humanitarian organizations to raise a crop of professional musicians. Their assignment will among other things be to offer free music lessons, workshops, master classes, and performance opportunities to economically disadvantaged Nigerian youths. The program of such organization should aim to uplift underprivileged Nigerian youths academically, culturally and spiritually, while promoting self-expression and community awareness through music education. With such program, Nigerian youths can foster a deep connection between music and other inter-related creative employment activities to sustain themselves. The youths will, as well, gain the skills and talents that would enable them express their culture, struggles, and triumphs through music to sustain them in life.

Apparently, music education is a strategy for achieving much public good, and through direct programs and advocacy, institutions can promote music as an intervention to improve youth's successful employment outcomes and strengthen self development of communities. This appeals for the support of governmental and non-governmental organizations that will contribute towards the mission of enriching the lives of the Nigerian youths and their communities with music. For instance by giving music scholarship, music lessons, and musical instruments to youths who would not otherwise have access, and of course teaching the youths how to use these instruments. With his, the government will create a sense of human fulfillment for the jobless youths. The youths could be thought how to become singers, stage designers, song-writers, producers of original songs, and learn how to produce and shoot music videos and documentaries.

In support of the above advocacy outcomes, the Nigerian government may take a cue from Music Crossroads International (MCI), which is an international non-governmental organization that empowers youths through music programs in partnership with African state Governments. It provides the young people between ages of 15 and 25 in Zimbabwe, Mozambique, Malawi, Tanzania, and Zambia, with musical opportunities and exposure, in addition to training in music and life skills. The program, as Lasisi (2011) attested, has grown to reach some 5000 musicians and a combined audience of over 300,000 per annum spread across the five countries. Such program impact in youth enlightment has been achieved through over 40 annual festivals, performance training 
and international band tours, as well as workshops focused on music right awareness, social interaction, gender issues and HIV/AIDS prevention, organized by the 5 National Music Crossroads NGOs.

Corroboratively learning music and how to use musical instruments, as pointed out by Ifenkwe (2012) adulated, is a unique way of exposing the youths to beauty and interest that nurture excellence and creativity. Structured musical activities for youths during the non-school hours are means of preventing violence and drug abuse. Music is an instrument of peace, it provides an emotional release in a time of social conflict and stress. It can as well be used to enable restive Nigerian youths to develop tolerance, collaboration, talents and essential life skills, academic success, and support services and community building.

\section{Conceptual and Moral Implications of the Discussion}

Based on the foregoing discussion on music education as a means of youth empowerment in Nigeria, the following implications are drawn.

In the first place, music is not only a mirror of its time and place but also a world of windows, opening up many possibilities and alternatives for learners in life. By implication, the youths who are able to acquire marketable music skills will be inspired to understand personal potential, think boldly on how to bring about positive changes, and adjust to serve humanity with music knowledge and skills.

Secondly, music education is a means of character formation, the creation of aesthetic sensitivity which helps music education to sustain its major role of shaping, reflecting and radiating the cultural differences of the peoples and nation.

Thirdly, music as a spiritual socio-cultural artifact with a lot of intrinsic functional values, imparts the norms, values, duties, and traditions of the society to students and learners. All of the above demonstrate the fact that the roles of the musician are contributory as well as complementary to youth empowerment and national development. In other words the musician is not only knowledgeable in but also responsible for maintaining civil, moral, and congenial order of the society.

\section{Recommendations}

From the paper's discussion based on the implications drawn, the following recommendations are proffered:

Nigerian government and well meaning people of the country should not think twice to invest on music education enterprise. The rationale behind this is that since music is a common language that reaches across boundaries to bring cultures together and to create a global understanding, it is a better option for the restive and militant Nigerian youths.

For the fact that music education is a performance art or experience which has a formative effect on the mind, life, and physical ability of the learner, government at all levels should embark on providing professionals to teach and direct music education at all school levels. This will enable Nigerian youths discover their talents and other natural endowments.

\section{Conclusion}

This paper has striven to demonstrate the enormous potential of music educative enterprise. It highlights that music is a performance art of language which has to be learnt through educational process. The paper affirms that from time and date, philosophers and poets have attested that music has the power of producing certain formative effects on the mind, character and physical ability of the learner. To this end the paper contends to maintain that since music education is capable of inculcating the skills of innovation and creativity for self and national development in the learner, it is a tool for youth empowerment.

\section{References}

Balogun, O. A. (2008). The Idea of an “Educated Person” in Contemporary African Thought. Journal of Pan Africa Studies, 13, 5-15.

Benton, H. H. (1974). The New Encycopaedia Britannica (15th ed., pp. 662-749). Chicago: Encycopaedia Britannica Inc. Burtt, E. A. (2008). Principles and Problems of Right Thinking in Music (Revised Edition). Chicago: Chicago University.

Byrne, C., \& Sheridan T. (2008). Music Is a Source of Deep Imaginative Satisfaction. British Journal, of Music Education, 15, 25-30. 
Egbunefu, L. (2012). Repositioning Nigerian Youths for Tomorrow. The Tide. http://www.thetidenewsonline.com/2012/04/16/repositioning.nigeiran.youths-for-tomorrow/

Elliot, D. J. (1995). Music Makers: New Philosophy of Music Education. New York: Oxford University Press.

Emielu, A. (2005). Towards a Sustainable Development of the Music Industry in Nigeria. Nigerian Theatre Journal, 8 , 298-384.

Federal Government of Nigeria (2004). National Policy on Education (4th ed.). Yaba Lagos: NERDC.

Gardiner, M. F. (2003). What Makes Music Work for Pubic Education? Journal for Learning through Music, 7, 87.

Grube, G. M. A., \& Reeve, C. D. C. (1992). Plato Republic. Indiana: Hackett Publishing Company, Inc.

Ifenkwe, G. E. (2012). Mobilizing and Empowering Youths for Sustainable Community and Rural Development in Nigeria. International Journal of Academic Research in Progressive Education and Development, 1, 144-152. http://www.hrmars.com/admin/pics/769.pdf

Lasisi, D. (2011). Youth Empowerment Is Key to Nation Building: Dr. Mimike, Ondo State Governor. http://www.ondostate.gov.ng/press/release/youth\%20empowerment.pdf

Marius, R. (1991). Random House Webster's College Dictionary (Glencoe Edition). New York: Random House Inc., 1015.

Ndibe, O. (2013). A Nation at War with Its Peoples. The Nigerian Oracle. http://thenigerianoracle.com/2013/04/30/a-nation-at-war-with-its-people-by-okey-ndibe/

Nwökenna, E. N. (2008). Active Learning: A Means for Producing Students with Life Long Learning Skills in Music Education. In B. G. Nworgu (Ed.), Education in the Information Age: Global Challenges and Enhancement Strategies (pp. 31-38). Nsukka: University Trust Publishers.

Okafor, R. C. (2007). Focus on Music Education in Nigeria. International Journal of Music Education, 2, 10-18.

Oluwaseyi, O. A. (2009). African Concept of Education: A Panacea to the Problem of Leadership. Nigerian Journal of Educational Philosophy, 21, 29-39.

Reimer, B. (1989). A Philosophy of Music Education. Englewood Cliff, NJ: Prentice-Hall.

Somefun, O. A. (2013). Youth Empowerment and Development Drive-An Invaluable Step to Secure Prosperity. http://oluwasegun27.wordpress.com/2013/09/20/youth-empowerment-and-devemploment-drive-an-invaluable-step-to-sec ure-nigerias-future-propserity

Wood, S., \& Wood, A. S. (1901). Shakespeare’s Julius Ceasar. London: George Gill \& Sons, Ltd. 
Scientific Research Publishing (SCIRP) is one of the largest Open Access journal publishers. It is currently publishing more than 200 open access, online, peer-reviewed journals covering a wide range of academic disciplines. SCIRP serves the worldwide academic communities and contributes to the progress and application of science with its publication.

Other selected journals from SCIRP are listed as below. Submit your manuscript to us via either submit@scirp.org or Online Submission Portal.
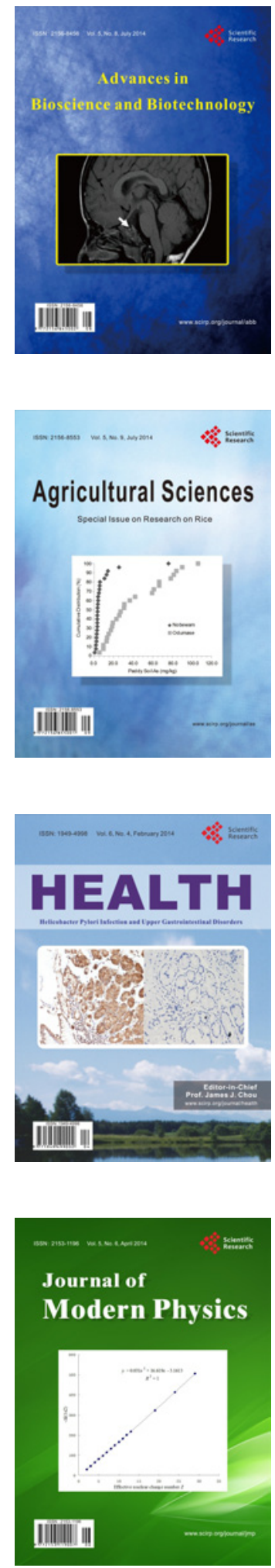
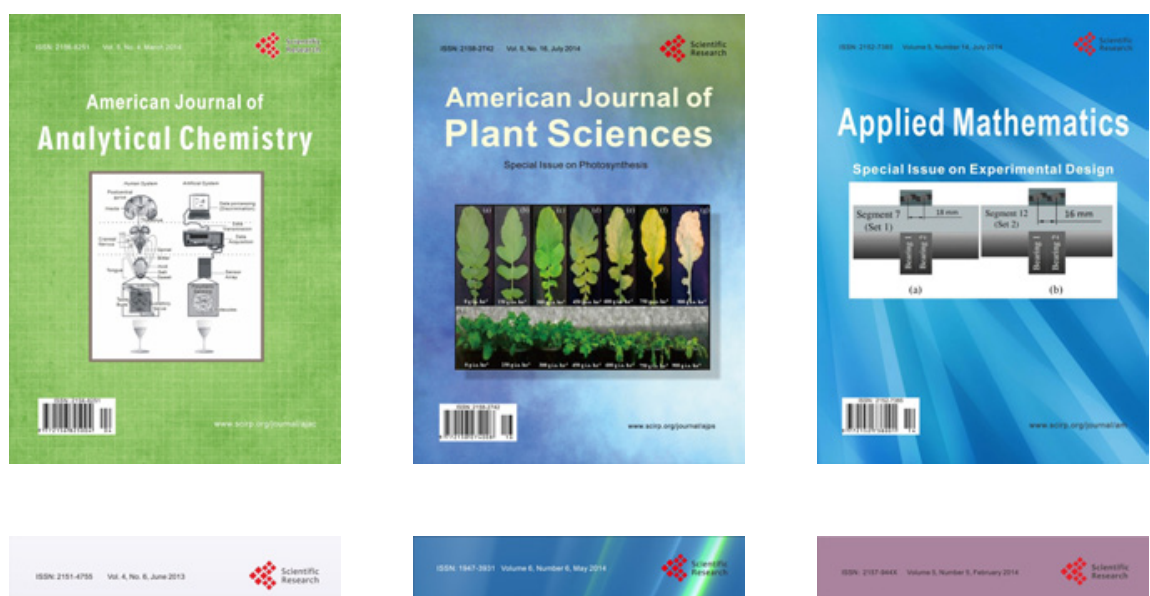

Creative Education
